\title{
The effect of pictorial story media on critical thinking of grade 4
}

\section{SDN 1 Pendem}

\author{
${ }^{1}$ Yulina Ismiyanti, ${ }^{2}$ Novia Dwi Permatasari \\ 1yulinaismiyanti@unissula.ac.id \\ 1Pendidikan Guru Sekolah Dasar, Fakultas Keguruan dan Ilmu Pendidikan, \\ Universitas Islam Sultan Agung \\ 2SDN 1 Pendem
}

\begin{abstract}
The background of this research is that teachers have not used innovative learning media in social studies learning which still tends to be conventional. Critical thinking ability is less motivated due to not using learning media as a facility. The purpose of this study was to analyze the influence of pictorial story media on critical thinking skills. This type of research is an experiment with a pre-test post-test control design. The total population was 40 class 4 students of SDN 1 Pendem. The sample was taken randomly with a significant amount of 5\% to obtain 36 students. The data collection used was a critical ability test as the main data, interviews, and documentation as supporting data. The pre-test test instrument includes validity, reliability, discriminating power, and level of difficulty. The data were tested with the normality test, because the data were obtained with a normal distribution, the t-test was tested. The test results obtained $t$ count $=>-t$ table or $9.668=>-2.030$. It can be concluded has $a$ significant effect on the use of pictorial media stories on critical thinking skills.
\end{abstract}

Keywords: learning media, pictorial story, critical thinking

Received: Dec 9 $9^{\text {th }}, 2020 \quad$ Reviewed: June $3^{\text {rd }}, 2021 \quad$ Accepted:July 6 $6^{\text {th }}, 2021 \quad$ Published:July $31^{\text {st }}, 2021$

\section{INTRODUCTION}

In an education process, the teacher is one of the important factors which also supports the achievement of the education plan as in the 2003 Constitution No. 2003 (Dalyono, 2015). Teachers must consciously be able to plan a teaching activity that is systematically arranged by utilizing everything to support the interest in teaching. Innovation is needed in terms of designing a system which is a set of specific methods, models, and strategies to be able to produce new solutions to existing problems. The system design also includes the use of learning media. Nowadays, many elementary schools use the 2013 curriculum with integrated material from various fields of subjects. In the 2013 curriculum learning process, there are three things students must acquire in each subject, namely attitudes, skills, and knowledge. The target in the 2013 curriculum is to form a qualified generation 
capable of competing with the world community from not only knowledge but also attitudes and skills (Giriyanti et al., 2021).

Curriculum 2013 requires the activeness of students in learning, where teachers not only do teaching activities but also have to think about how the process of transferring knowledge can occur, namely how students can understand teaching materials to be able to master the material. The purpose of social studies education in the 2013 curriculum is to produce citizens who have knowledge and understanding of society and their nation, are religious, honest, democratic, creative, critical analytical, enjoy reading, can learn, are curious, care about the social and physical environment, contribute to the development of social and cultural life, as well as communicate and be productive. The ability to think critically is one of the social studies goals contained in elementary school the 2013 curriculum (Astra et al., 2021)

The results of observations at class 4 SD Negeri 1 Pendem show that in social studies learning, the teacher is not yet innovative in learning media. The amount of social knowledge material and lack of innovation in terms of learning media is one of the causes of student's low ability to think critically. Social science material that is studied conventionally and theoretically makes students bored. In learning students just sit, be quiet, listen, and take notes. As a result, students' critical thinking skills do not develop.

The use of less innovative learning media is one of the causes for the low critical thinking skills of students. General media is something that can make students more motivated to learn more critically and more easily digest the knowledge conveyed or the information conveyed becomes more concrete. So the media is not only interesting but must be able to increase knowledge, change the attitudes of students, and add skills. In the learning process, the media is a container and channel of messages to students. Learning media is used as an intermediary or tool in facilitating the teaching and learning process to achieve effective and efficient teaching goals. The use of media in the classroom or the learning process is an important requirement. Learning media are all things that can facilitate the delivery of learning material and can increase student interest in learning. (Kumala et al., 2021). So the task of learning media is not just communicating the relationship between teachers and students, but more than that where the media are an integral part that is interrelated between one component and another that interacts supports each other, and influences each other. 
Social studies lessons are thematically integrated with other subject areas. So that the teacher has difficulty in achieving learning goals. In the learning process, students have a variety of different critical thinking abilities. The ability to be a bit critical is a creative ability that can explain an event, think about the implications of the findings, and apply new knowledge to individual and social problems (SánchezIbáñez et al., 2021).

In modern education, critical thinking is an important thing to develop. Critical thinking is something that is needed in democratic life. Student's critical thinking skills to solve each problem appropriately, identify information and causes from existing data and facts. Then find solutions and re-analyze the effectiveness of the resulting problems. (Rababa, 2021).

Critical thinking indicators are as follows: interpreting, analyzing and identifying, evaluating, drawing conclusions, explanations, and independence. Interpreting is categorizing and classifying. analyze, test, and identify. Evaluating is considering and conclude. Concluding, namely watching the data and explaining the conclusion. An explanation is writing down the results and presenting arguments. Independence, namely making corrections and testing (Lane \& Oswald, 2016).

To learn social science for students in elementary school, there are few difficulties, if there are no supporting learning media. Then there must be the right solution to overcome the problems that occur. So that a learning media for social knowledge is needed that not only facilitates. But also can develop students' thinking to be able to think critically about various problems in daily life. So that students can solve a problem that is certainly by the objectives of social knowledge itself. Teachers must be aware that without the help of media, teaching materials will be difficult for students to digest, especially for complex subjects. Learning media is a vehicle for channeling information in learning activities. With the media, students will be easier to interpret teaching materials. However, making a learning media must be in line with the content and purpose of the teaching that has been formulated. So that the function of learning media becomes right on target (SánchezIbáñez et al., 2021).

One of the media that can be used in social studies learning and can develop students' critical thinking skills is Pictorial Story Book learning media. The picture book story contains a series of pictures complete with stories related to learningrelated material images. In other words, the learning material is packaged with pictures and explanations or stories (Rahman et al., 2020). 
In the Pictorial Story Book, there are three components image, text, and exercise questions. Image can represent the contents of the written story, which can lead to more imagination for students so that the understanding process in the story will be better. In the Pictorial Story Book, images are used to support the content of the story, so in each picture, there are two to four pictures to support the content of the story. The text includes several things, such as content that covers the curriculum, language whose scope is following children's development, using communicative language, and interesting presentation. Exercise questions presented in the Pictorial Story Book media are questions that can develop students 'critical thinking skills related to stories and students' daily lives (Wismaliya et al., 2018).

In addition, the Pictorial storybook presents questions that must be done by students to develop critical thinking skills and better understand their social life. In this study, the pictorial story learning media was limited to subteam 1 "Cita-Citaku", in class 4 of elementary school. The results of this study are theoretically useful as references and knowledge studies related to the media pictorial story. The practical benefit for students is to develop critical thinking skills. Making learning active, interesting, fun, and meaningful with the pictorial story learning media. The frame of mind in this study is.

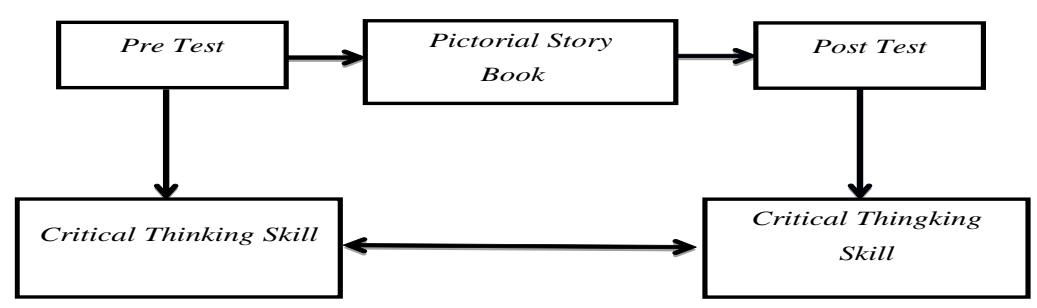

Picture 1. Framework of Thinking

The research hypothesis is as follows. H1: There is a significant influence on pictorial storybook learning media on students' critical thinking skills in class 4 social science subjects at Primary School 1 Pendem. H0: There is no significant influence on pictorial storybook learning media on students' critical thinking skills in class 4 social science subjects in Primary School 1 Pendem. The purpose of this research find out whether there is an influence of learning media Pictorial Story Book on students' critical thinking skills in the social studies subject with the theme "Cita-Citaku" class IV SDN 1 Pendem 


\section{METHOD}

This research is an experimental study with the design of one group pre-test post-test design. The variables in this study are independent variable is pictorial storybook learning media and the dependent variable is critical thinking ability (Muntholib et al., 2021). The population can be interpreted as the whole of the object under study. The population in this study were 4th-grade students at Pendem 1 Elementary School with a total of 40 students. The sample is partially or representative of the population being examined. This research uses the Probability Sampling technique with the type random sampling technique. The taking of sample members from the population is done randomly without regard to the same strata that are in that population. Each member of the population is given a number. Because of random retrieval, then every member of the population has the chance that is the same to be chosen. In this research, using a population of 40 students, the sample will be taken by a sample of 36 students based on table Kreijcie and Morgan with a significant level of 5\% (Kurjum et al., 2020).

\section{Data Collection Techniques and Instruments \\ Critical Thinking Ability Test}

Test sheets are used to determine learning outcomes on cognitive aspects in this study. The test technique is used to obtain data about the students' critical thinking skills that are applied in the pre-test and post-test. The test technique used is in the form of description questions. The questions of critical thinking ability tests were previously tested for validity, reliability, differentiation data, level of difficulty as follows (Wismaliya et al., 2018). Based on the results with the biserial correlation coefficient formula of the validity test of 20 questions that have been tested there are 18 valid questions and 2 invalid questions the number questions 15 and 19. To determine the reliability of 18 valid questions with the formula of the spearmanbrown formula, it can be seen that the reliability coefficient is obtained at 1.12193 so that it is included in the "very high" category. The results of the calculation of distinguishing power for the problem description show that out of the 18 description questions 7 description questions are included in the "sufficient" category and 11 description questions including the "very good" category. Calculation of the level of difficulty of the description questions from 18 questions, there are 3 questions including the "easy" category, 13 questions including the "sufficient" category, and 2 questions including the "difficult" category. 


\section{Interview}

The interviews used are interviews that are not structured. Interviews were conducted before the treatment or the implementation of the research (Ismiyanti, 2018). These interviews were used as the initial data to find out about the problems of media use and the ability to think critically about students. Interviews were conducted with the class 4 teacher of the Elementary School 1 Pendem, namely Novia Dwi Permatasari.

\section{Documentation}

The documentation study sheet is intended to obtain data directly from the research site of the photos during the study, data on class 4 students and teachers at the elementary school is Pendem 1 , letters of permission for conducting research $(\mathrm{Al}$ Sultan et al., 2021).

\section{Data Analysis}

To calculate the value of critical thinking skills pre-test and post-test, each student is used by the formula (Arikunto, 2019).

$$
\mathrm{N}=\frac{\text { student score }}{\text { score total }} \times 100 \%
$$

1. Normality Test

The normality test aims to find out whether the data is normally distributed. The condition of normally distributed data is a requirement in testing hypotheses using parametric statistics. The hypothesis used is H1: data is normally distributed, H0: data is not normally distributed. This study using the Liliefors test (Sundayana, 2019).

2. T-Test

To test the hypothesis the significance test is used with the t-test. The $t$ test is used to find out the hypothesis that has been proposed. The t-test formula used is:

Determine $t$ count and $t$ table

$\mathrm{t} \_$count $=\left(\mathrm{x}^{-}-\mu \_0\right) /(\mathrm{s} / \sqrt{\mathrm{n}})$

$\mathrm{t}_{-} \mathrm{table}=\mathrm{t}_{-} \alpha(\mathrm{dk}=\mathrm{n}-1)$

If $\mathrm{t}$ count $>=\mathrm{t}$ table then $\mathrm{H} 1$ is accepted (Sundayana, 2019). 


\section{RESULT AND DISCUSSION}

\section{Result}

\section{Pre-test Result}

To find out the initial ability of class IV students, a pre-test is given first. A pre-test is conducted on Monday, March 12, 2021, in the first hour. Based on the results of the score from the pre-test, it can be seen the results of students' critical thinking skills before the treatment is as follows. The highest score when the pretest is 83 and the lowest score is 48 with an average of 65.975 .

Table 1. Achievement of the pre-test of students' critical thinking ability for each indicator

\begin{tabular}{lc}
\hline \multicolumn{1}{c}{ Indicator } & Percentage \\
\hline Interpret & $72 \%$ \\
Analyze & $58 \%$ \\
Evaluating & $65 \%$ \\
Interesting Conclusion & $67 \%$ \\
Explanation & $55 \%$ \\
Independence & $44 \%$ \\
\hline
\end{tabular}

Next is to test the normality of the data from the pre-test results. The purpose of this test is to find out whether the data is normally distributed with Liliefors formula. Based on the normality test the results of the pre-test $\mathrm{L}$ max: 0.087 < L table: 0.148 so that it is declared "normal distribution".

After the data is known to be normally distributed then hypothesis testing is done with the t-test. Based on the t-test results of the pre-test with $t$ count $=-6,277$ and $t$ table $=-2,030$ with a significant level of $5 \%$. The test results show that $t$ count $=<-\mathrm{t}$ table or $-6,227<-2,030$ with $\mathrm{H} 1$ testing criteria rejected. This means that there is no significant difference between the pre-test and post-test critical thinking skills with the Pictorial Story Book media.

\section{Post-test Result}

Post-tests were conducted to determine the results of students' critical thinking skills after being treated. Post-test is held on Tuesday, March 13, 2021. Below is the post-test data. The highest score when the post-test is 97 and the lowest score is 75 with an average of 86.883 . 
Table 2. Achievement of the post-test of students' critical thinking ability for each indicator

\begin{tabular}{lc}
\hline \multicolumn{1}{c}{ Indicator } & Percentage \\
\hline Interpret & $95 \%$ \\
Analyze & $93 \%$ \\
Evaluating & $85 \%$ \\
Interesting Conclusion & $81 \%$ \\
Explanation & $80 \%$ \\
Independence & $85 \%$ \\
\hline
\end{tabular}

After that, the normality of the results of the post-test data was carried out. And the normality test results of the post-test L max: $0.141<\mathrm{L}$ table: 0.148 then it can be stated as "normal distribution". The next step is to test the hypothesis with the help of MS. Excel, it is known that $\mathrm{t}$ count $=>-\mathrm{t}$ table or $9.668=>-2.030$ with $\mathrm{H} 1$ testing criteria accepted. So based on the above test shows that there is an influence of learning media Pictorial Story Book on students' critical thinking skills in social studies subjects in the fourth grade of Primary School 1 Pendem. It means that it can be concluded that there is a significant influence on Pictorial Story Book media variable ( $\mathrm{x}$ variable) on critical thinking ability (variable y).

\section{Discussion}

This research was conducted in 2 meetings in the experimental class. In this study, only one class was used, namely only the experimental class, by looking at the results of the pre-test and post-test. The pre-test before the treatment and post-test was carried out after the treatment. At each meeting, the students conducted a question and answer session and discussion aimed at developing students' critical thinking skills.

Based on the normality test results of the pre-test $L$ max: $0.087<$ L table: 0.148 so that it is declared "normally distributed". And the normality test results of the post-test L max: $0.141<\mathrm{L}$ table: 0.148 then it can be stated as "Normally Distributed" So the next step is to test the hypothesis with the help of MS. Excel, note that $\mathrm{t}=>-\mathrm{t}$ table or $9.668>-2.030$ with the $\mathrm{H} 1$ test criteria accepted. So based on the test above, it shows that there is an influence of the Pictorial Story Book learning media on student's critical thinking skills in class 4 social science subjects theme of "Cita-Citaku" subject, SDN 1 Pendem. So that there is a significant influence of the Pictorial Story Book (X) media variable on the critical thinking ability variable (Y). 
There is a significant effect of Picture Storybook media on critical thinking skills, such as research on the influence of E-learning in developing critical thinking. The results of E-learning can facilitate the learning process, namely overcoming socio-cultural barriers (Rababa, 2021).

Critical thinking is very useful if you are used to using it, this ability can improve your understanding in many contexts (Huber \& Kuncel, 2016). Through the Pictorial Story Book media, students become more critical in the learning process. Through pictorial story media, students become interested in participating in learning. It contains a series of pictures accompanied by explanations related to social science learning materials. Students seem to study social studies material like reading a picture story. This makes students more critical to learn more about social science learning materials. From the pre-test and post-test results, it was also explained that the post-test results were given treatment through the Pictorial Story Book media, the results were very different from those before the treatment, where the students' critical thinking skills were better after being given treatment. In addition, the use of learning media can foster new desires and interests, motivation, and stimulation in learning, and even have a psychological influence on students in learning (Endiawan et al., 2021). Through the Pictorial Media Story, there is a lot of interaction between students and teachers and students and students (Kesler et al., 2021). All students are required to be able to speak in class, so it is not only smart students who often speak. The atmosphere that occurs in the learning process becomes more fun and conducive. So that students become easier to accept the lessons that are given.

\section{CONCLUSION}

It can be seen the test scores of students' critical thinking skills using Pictorial Story Book media. The value of the pre-test with the highest score is 83 and the lowest value is 48 . While the post-test scores get the highest score of 97 . And the lowest value is 75 with an average value of 65.5 and 86 . From this explanation, it is known that the post-test value is higher than the pre-test value. Based on the analysis, it can be stated that the use of Pictorial Story Book media that is applied influences students' critical thinking skills. Based on the normality test the results of the pre-test L max: $0.087<$ L table: 0.148 so that it is declared "normal distribution". And the normality test results of the post-test $L$ max: $0.141<\mathrm{L}$ table: 0.148 then it 
can be stated as "normal distribution". The next step is to test the hypothesis with the help of MS. Excel, it is known that $\mathrm{t}$ count $=>-\mathrm{t}$ table or $9.668=>-2.030$ with $\mathrm{H} 1$ testing criteria accepted. So based on the above test shows that there is an influence of learning media Pictorial Story Book on students' critical thinking skills in social studies subjects in the fourth grade of Primary School 1 Pendem. It means that it can be concluded that there is a significant influence on Pictorial Story Book media on critical thinking ability.

\section{ACKNOWLEDGEMENTS}

Thanks and appreciation to PGSD, FKIP, UNISSULA for supporting this article until publication, and Novia Dwi Permatasari, class 4 elementary school teacher of Primary School 1 Pendem as a collaborator in this research.

\section{REFERENCES}

Al Sultan, A., Henson, H., \& Lickteig, D. (2021). Assessing preservice elementary teachers' conceptual understanding of scientific literacy. Teaching and Teacher Education, 102. https://doi.org/10.1016/j.tate.2021.103327

Arikunto, S. (2019). Prosedur Penelitian. Rineka cipta.

Astra, I. M., Susanti, D., \& Wulandari. (2021). The effects of active learning model team quiz type assisted by animation video on critical thinking ability of high school students. AIP Conference Proceedings, 2320. https://doi.org/10.1063/5.0037590

Dalyono, M. (2015). Psikologi Pendidikan. Rineka cipta.

Endiawan, A. S., Fathurohman, I., \& Santoso. (2021). Development design technology comic literacy android based e-book. Journal of Physics: Conference Series, 1823(1). https://doi.org/10.1088/1742-6596/1823/1/012072

Giriyanti, P., Supriatno, B., \& Rustaman, N. Y. (2021). The development of diffusion and osmosis practicum activities based on the practical work domain along with curriculum progresses in Indonesia. Journal of Physics: Conference Series, 1806(1). https://doi.org/10.1088/1742-6596/1806/1/012161

Huber, C. R., \& Kuncel, N. R. (2016). Does college teach critical thinking? A metaanalysis. Review of Educational Research, 86(2). https://doi.org/10.3102/0034654315605917

Ismiyanti, Y. (2018). Pengaruh minat dan kedisiplinan terhadap nilai UAS IPS di SDN 02 Temulus. Jurnal Ilmiah Pendidikan Dasar, 5(1), 34-43. https://doi.org/10.30659/pendas.5.1.34-43

Kesler, T., Darrell, K., Moss, Y., Pasternak, J., \& Valco, A. (2021). Designing on the page: Composing picturebooks in a Kevin Henkes author study. Journal of Early Childhood Literacy. https://doi.org/10.1177/1468798421995527

Kumala, F. N., Ghufron, A., Astuti, P. P., Crismonika, M., Hudha, M. N., \& Nita, C. I. R. (2021). MDLC model for developing multimedia e-learning on energy concept for primary school students. Journal of Physics: Conference Series, 1869(1). https://doi.org/10.1088/1742-6596/1869/1/012068

Kurjum, M., Muhid, A., \& Thohir, M. (2020). Think-pair-share model as solution to 
develop students' critical thinking in islamic studies: Is it effective? Cakrawala Pendidikan, 39(1). https://doi.org/10.21831/cp.v39i1.28762

Lane, D., \& Oswald, F. L. (2016). Do 45\% of college students lack critical thinking skills? Revisiting a central conclusion of academically adrift. Educational Measurement: Issues and Practice, 35(3), 23-25. https://doi.org/10.1111/emip.12120

Muntholib, M., Hidayati, K., Purnajanti, L., Utomo, Y., \& Hariyanto, H. (2021). Impact of explicit scientific inquiry instruction on students' scientific argumentation skills in salt hydrolysis. AIP Conference Proceedings, 2330. https://doi.org/10.1063/5.0043237

Rababa, N. (2021). The effect of e-learning in developing high thinking skills. International Journal of Data and Network Science, 5(1), 43-46. https://doi.org/10.5267/j.ijdns.2020.11.004

Rahman, M. I., Mustakim, M., \& Elihami, E. (2020). The capability enhancement training reading comprehension: First and second grade in Enrekang Regency through pictorial story media and SQ3R method. Maspul Journal of Community Empowerment, 1(1), 70-79.

Sánchez-Ibáñez, R., Guerrero-Romera, C., \& Miralles-Martínez, P. (2021). Primary and secondary school teachers' perceptions of their social science training needs. Humanities and Social Sciences Communications, 8(1). https://doi.org/10.1057/s41599-021-00705-0

Sundayana, R. (2019). Perbandingan desain pembelajaran ASSURE dan PPSI untuk meningkatkan kemampuan pemecahan masalah matematis dan kemandirian belajar. Mosharafa: Jurnal Pendidikan Matematika, 8(1), 143-154. https://doi.org/10.31980/mosharafa.v8i1.420

Wismaliya, R., Hakam, K. A., \& Agustin, M. (2018). Model of learning cognitive moral development through pictorial story in elementary school. International $E$ Journal of Advances in Education, 4(10), 77-85.

Conflict of Interest Statement: The authors declare that the research was conducted in the absence of any commercial or financial relationships that could be constructed as a potential conflict of interest. 